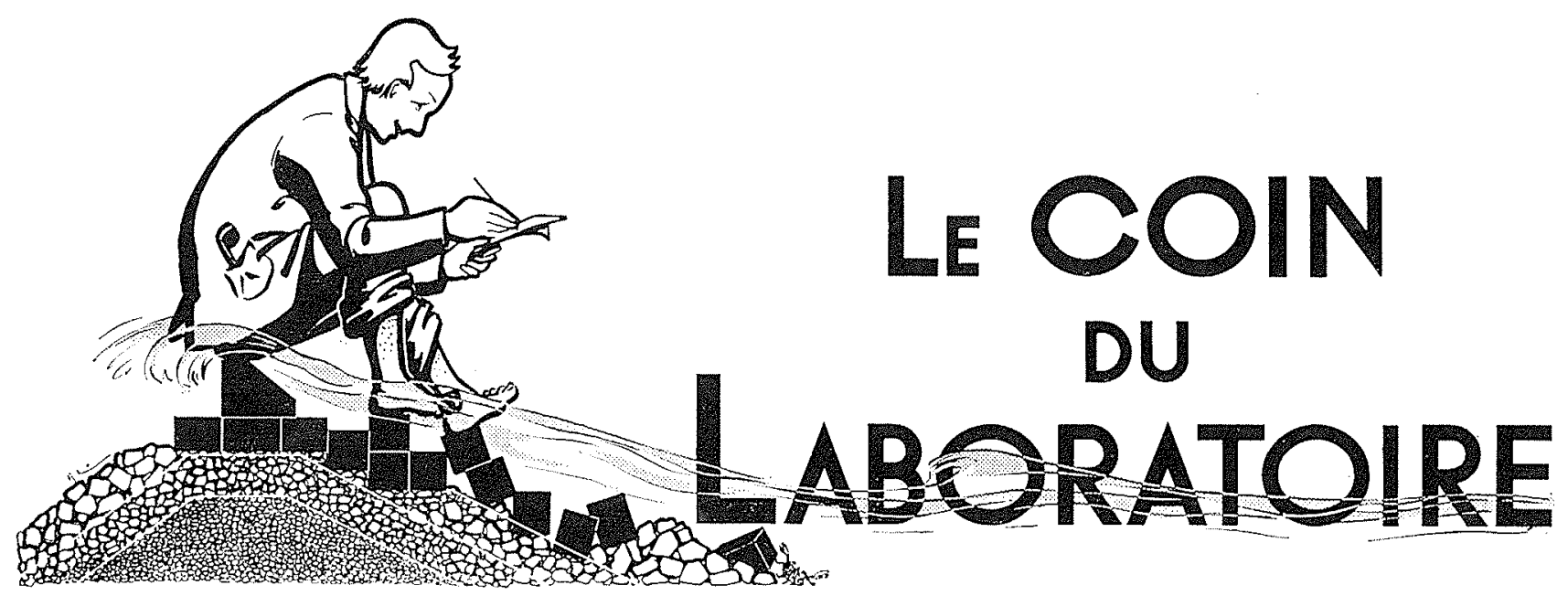

\title{
Description d'une installation d'études expérimentales sur la physique de la houle
}

English text, p. 848 .

\begin{abstract}
Description des dispositifs assurant la produclion, l'épuration, puis le renforcement d'une houle présentant le maximum de pureté. Possibilite de modifier, en cours dessai et à dislance, les caracteristiques de la houle. Procédé original pour lamelioralion des conditions d'amortissement.
\end{abstract}

Les etudes faisant intervenir la houle expérimentale produite en canal concernent le plus souvent des maquettes d'ouvrages en projet, dont il s'agit de définir les qualités : stabilité, absence de franchissements, pouvoir absorbant, parmi les principales.

Dans ce cas, la production d'une houle de caractéristiques constantes dans le lemps permel, si l'on évite des réflexions trop importantes sur le systeme générateur de houle, d'obtenir des résultals en général suffisamment fidèles pour qu'on puisse comparer entre eux différents types d'ouvrages.

Cependant, ces conditions sont nettement insuffisantes lorsqu'on étudie la physigue de la houle, c'est-à-dire lorsqu'on veut mettre en évidence, avec une précision suffisante, la strueture même el les caractéristiques du phénomène de la houle, afin de pouvoir notamment comparer ces résultats avec les données de la théorie.

Il faut ahors un outil expérimental spécialement adapté à ces études physiques. C'est une longue suite de perfectionnements, dont nous allons décrire iei les plus caractéristiques, qui a permis d'obtenir, sur l'une des installations du
Laboratoire Dauphinois d'Hydraulicue, une houle particulierement pure et constante.

Cette installation devait offrir le maximum de possibilités expérimentales, notamment pour l'obtention des houles fortement cambres. On admet en général que ceci est incompatible avec l'emploi de fillres, nécessaires pour absorber les réllexions sur le batteur, mais qui absorbent dgatlement une partie de l'énergie de la houle incidente.

Le problime a été résolu par l'emploi d'un convergent placé entre le batteur a houle et le canal d'études. Ce convergent " concentre » en quelque sorte l'énergie de la houle et renforce son amplitude.

La convergence a été prévue de manière à compenser exactement la perte d'énergie dans les filtres, ainsi que l'amortissement propre.

L'installation comprend alors :

La partic large avec le batteur à houle et les filtres, le convergent, le canal d'études proprement dit où se trouve la partie vitrée, et l'amortisseur d'extrémité. Cet ensemble est complété par une conduite d'équilibrage dont nous expliquerons l'utilité. 


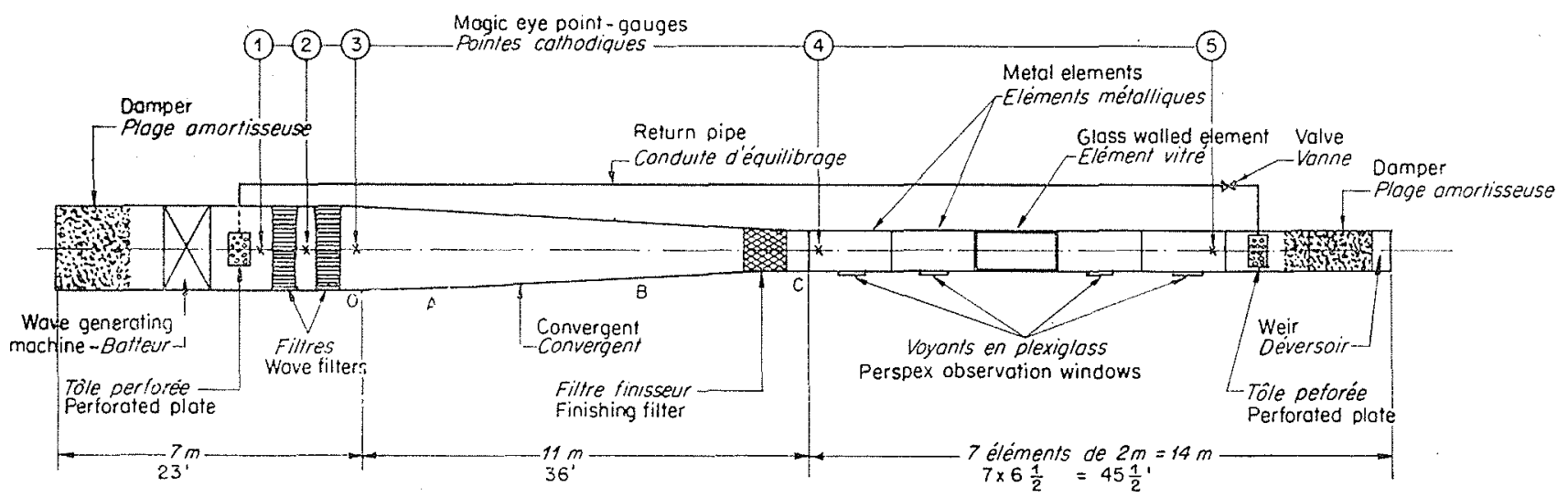

Fig, 1.

Partie large. - Elle comporte trois éléments métalliques de 0,75 m de largeur, d'une longucur totale de $7 \mathrm{~m}$. Cást dans cette région que se trouve le batteur à houle. Derrière celui-ci est aménagée une plage en enrochements, destinée à absorber la houle secondaire émise à l'opposé de la houle principale.

Devant le batteur sont disposés deux filtres à houle.

Convergent. - On s'est efforé de le prévoir extrèmement progressif, de manière à apporter

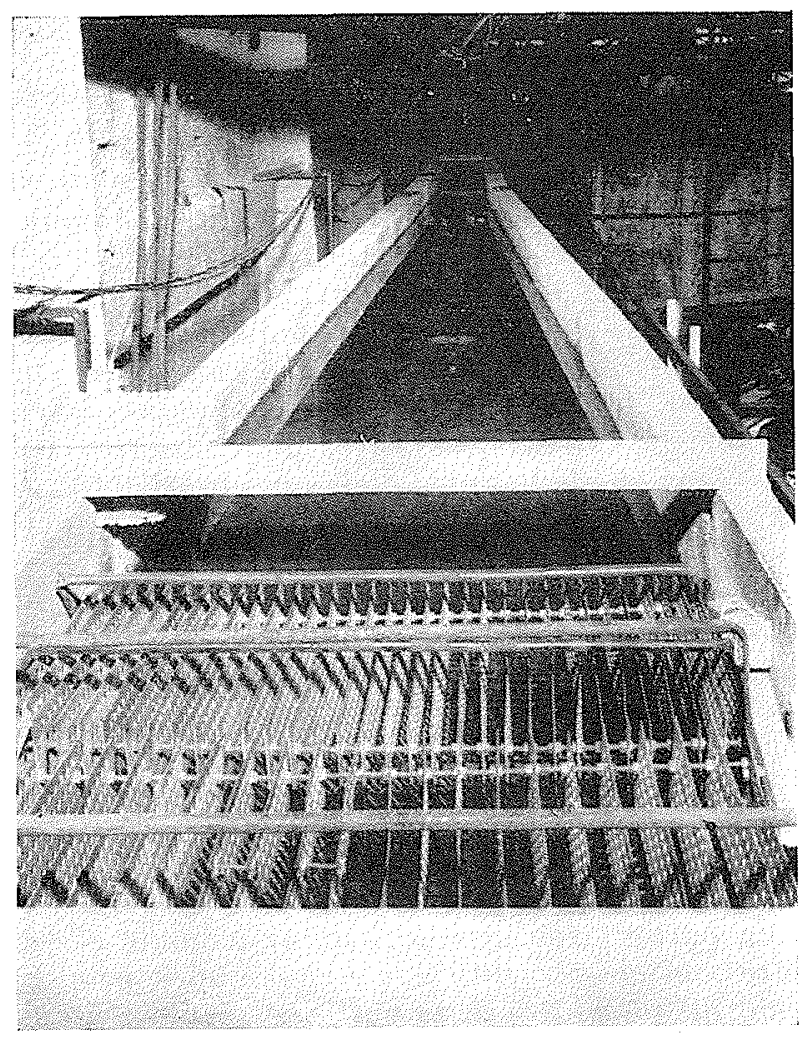

Fig. 2.

LE CONVERGENT aux conditions de propagation le moins de perturbations possible. En effet, une variation brutale de section, par exemple, entraine de forts balancements transversaux, des réflexions, etc.

La convergence adoptée est faible, puisque la variation de longuenr est de $0,45 \mathrm{~m}$ pour une longueur de $11 \mathrm{~m}$.

Nous avons rendu rectiligne la partie moyenne de la paroi, raccordée au reste de l'installation d'un côté par un are de parabole, de l'autre par un are de cubique (ayant au point de raccordement une courbure nulle). Ceci permet de concilier la convergence faible avec un raceordement très progressif.

La paroi a été réalisée en béton, ce qui offrait des facilités beaucoup plus grandes que la construction métallique pour le modelé des courbes choisies.

Le convergent est utilement complété par une série de guideaux longitudinaux évitant les légers balancements transversaux qui pourraient se produire pour certaines périodes particulières.

Canar vitré. - I est constitué par sept éléments métalliques de $2 \mathrm{~m}$ de longueur. Ces éléments sont, comme ceux de la partie large, construits en tôle inoxydable nervurée.

Chaque élément autre que le troisième porte dans sa partie centrale, sur chaque face latérale, une ouverture garnie d'une lame de plexiglass.

Le troisième élément à partir du convergent est vitré latéralement sur toute sa longueur, ceci en vue des observations visuelles et de la photographie.

Condutre D'ÉQuirmbrage. - Lorsqu'on étudie en canal une section d'une digue franchissable par la houle, il s'opère peu à peu derrière la digue, lorsque celle-ci est peu perméable, une « mise en charge» qui crée des conditions artificielles par rapport aux circonstances réelles. En effet, dans la réalité, l'eau qui franchit l'ouvrage retourne en général à la mer, par exemple par 


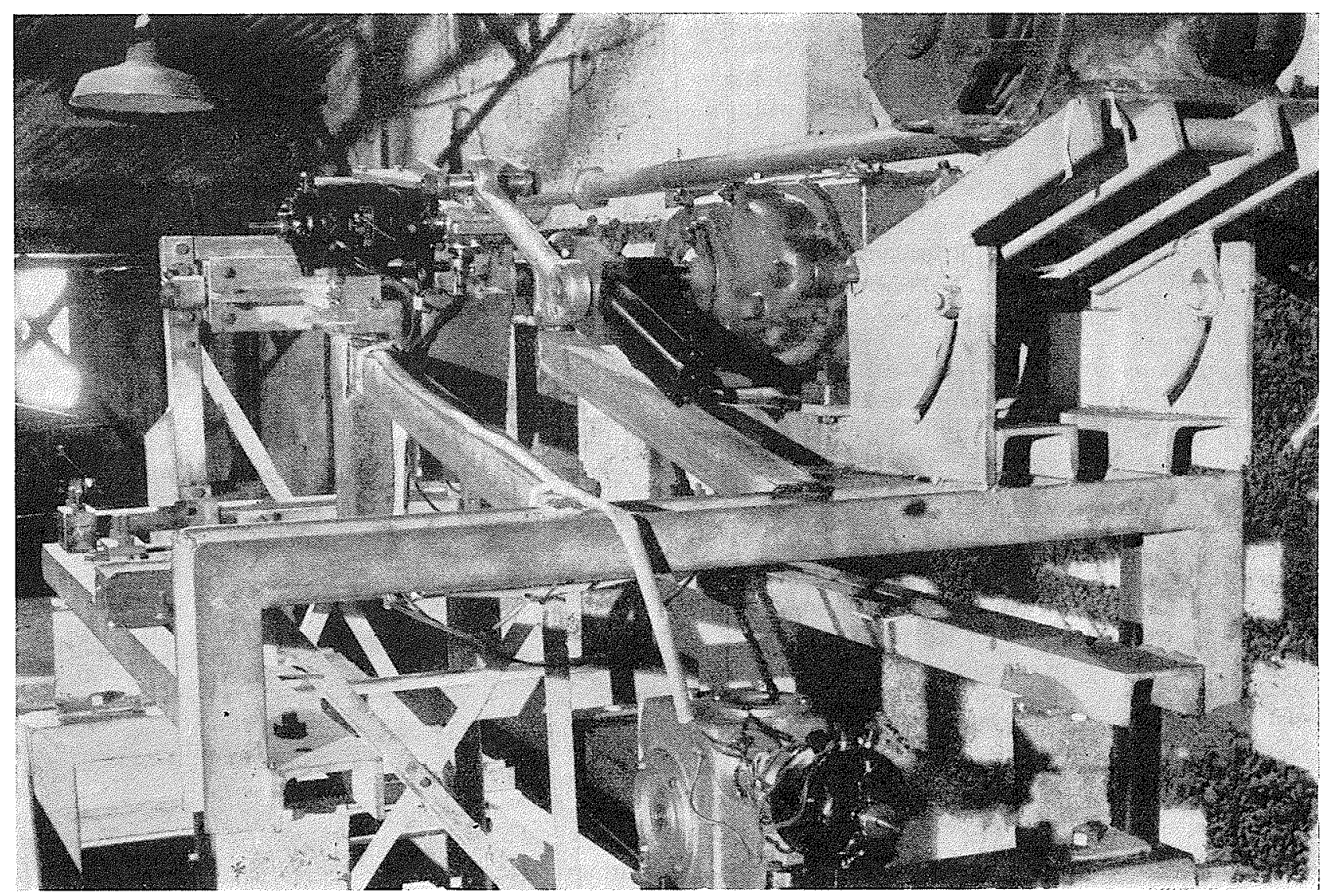

Jik. 3.

LA CONMANDE DU BATEEUR. - REMOTE CONTROR OF THE BLADE MOVEMENT.

une passe. Il faut done que l'eau qui franchit la maquette puisse elle aussi retommer vers le batteur. Pour cela, une conduite de fort diamètre (donc domnant une faible perte de charge) relie l'avant-dernier élément du camal à la région située immédiatement devant le batteur.

BatTeUr a Houle. - Il se rattache à la famille des volets plans oscillants.

Dans le système adopté, du type «balançoire», le volet est solidaire de l'élément moyen d'un trois barres. Ce volet est alors animé d'un mouvement complexe qu'on peut rendre très voisin de celui que doivent avoir les molécules d'eau. (Voir : Les appareils générateurs de houle en Laboratoire, par F. BIEsel et F. Suquet, la Houille Blanche, $\left.\mathrm{n}^{\circ \mathrm{s}} 2,1951 ; 4,1951 ; 5,1951.\right)$

COMMANDE A DISTANCE DES CARACTERISTYUUES DE LA HOULE. - Une particularité originale de ce batteur est que l'on peut agir à distance et en marche sur les paramètres dont dépendent les caractéristiques de la houle.

En effet, la transmission du mouvement se fait par deux bielles entre lesquelles se trouve interposé un levier intermédiaire, l'un des points d'articulation étant réglable le long de ce levier grâce ì un moteur auxiliaire. L'amplitude du mouvement du batteur peut ainsi être réglée à distance.

D'autre part, la période d'oscillation du batteur dépend du réglage d'un variateur de vitesse lui aussi commandé par un moteur auxiliaire.

On peut donc, à partir de la vitre d'observation, modiffer en marche les caractéristiques de la houle incidente (période et amplitude). Ceci offre un champ considérable de possibilités : on peut en particulier faire agir sur un ouvrage des trains de houle en faisant varier la période ou l'amplitude, ou les deux simultanément, suivant des cycles déterminés. On peut également ajuster de manière très précise les caractéristiques de houle en vue de la production d'un résultat déterminé, comme la cambrure limite de la houle ou la prósence de gifles sur un ouvrage.

Filtres a Hover. - La houle émanant du batteur passe dans un groupe de filtres du type à tôles perforées dont le principe a été décrit pré. cédemment par M. Breser (la Howille Blanche, mai-juin 1948).

Nous avons pu, ici encore, constater l'effet extrêmement favorable des filtres pour la régularisation du profil de la houle, en plus de son 
objet principal, qui est l'absorption des ondes réfléchies.

Un autre genre de filtres a été mis au point : il a une structure alvéolaire de faible densité qui amortit l'énergie de la houle d'une facon tris homogène. Ceci rend ses qualités hydrauliques tout à fait remarquables.

Un filtre de ce genre, que nous pourrions qualifier de « filtre finisseur», peut ètre disposé entre le convergent et la vitre d'observation, ceci afin d'améliorer encore le profil de la houle.

Amortisseurs a HOLle. - Le canal comporte à son extrémité un amortisseur destiné à absorber l'énergie de la houle incidente. Cet amortisseur est par exemple constitué par une plage perméable de grande longueur précédée de plusieurs filtres.

L'intérêt de la plage perméable est que, ici encore, la perte d'énergie n'est pas localiséc dans une région de l'absorbeur, mais est répartie dans toute la masse de celui-ci. Le profil de la plago est curviligne, ce qui permet d'avoir une pente tres fable au voisinage de la surface sans entrainer un encombrement total exagéré. Un tel profil, prévu pour un niveau donné, a ainsi un rendement meilleur qu'une pente uniforme.

L'effet de cette plage, joint à celui des filtres, permet ainsi d'éliminer presque completement les réflexions à l'extrémité du canal, ce qui est suffisant pour un grand nombre d'ctudes : mesures de célérité, mesures de courants de transport, etc. Cependant, la légère réflexion résiduelle est gènante pour certaines études très poussées sur la structure même de la houle, telles que des recherches sur la forme des profils ou des trajectoires internes.

Par exemple, dans un cas où toutes les précautions classiques sont prises pour éviter les réflexions à l'extrémité du canal, on constate que la faible houle réfléchie qui subsiste produit une organisation des trajectoires en chapelets.

Un autre procédé d’absorption était donc nécessaire. C'est un tel procédé qui a été mis au point, en accord avec la theorie de M. Bresel. (« Etude théorique de la réflexion de la houle sur certains obstacles ». Communication présentée à la Société Hydrotechnique de France le 19 juin 1951. Résumé dans le n"A-1952 de la Honille Blanche, p. 121.)

Dans le cas d'une légère réflexion, l'enveloppe du profil de la houle pendant la propagation est constituée par deux courbes dont les maximum et les minimum correspondent à ce qu'on peut appeler les «ventres» et les « nœuds» du clapotis partiel. Si l'on parvient à créer une seconde réflexion, telle que les ventres et les nœuds du deuxieme clapotis partiel prennent la place des nouds et des ventres du premier, l'ensemble de ces deux réflexions doit être tel qu'elles s'annulent et que la houle incidente soit pure.

C'est ce qu'on parvient à réaliser expérimentalement. La seconde réflexion est produite de la manière suivante : considérant les deux enveloppes de la houle incidente, on repère le plus exactement possible les nouds et les ventres du clapotis partiel. On plonge ensuite partiellement, de-

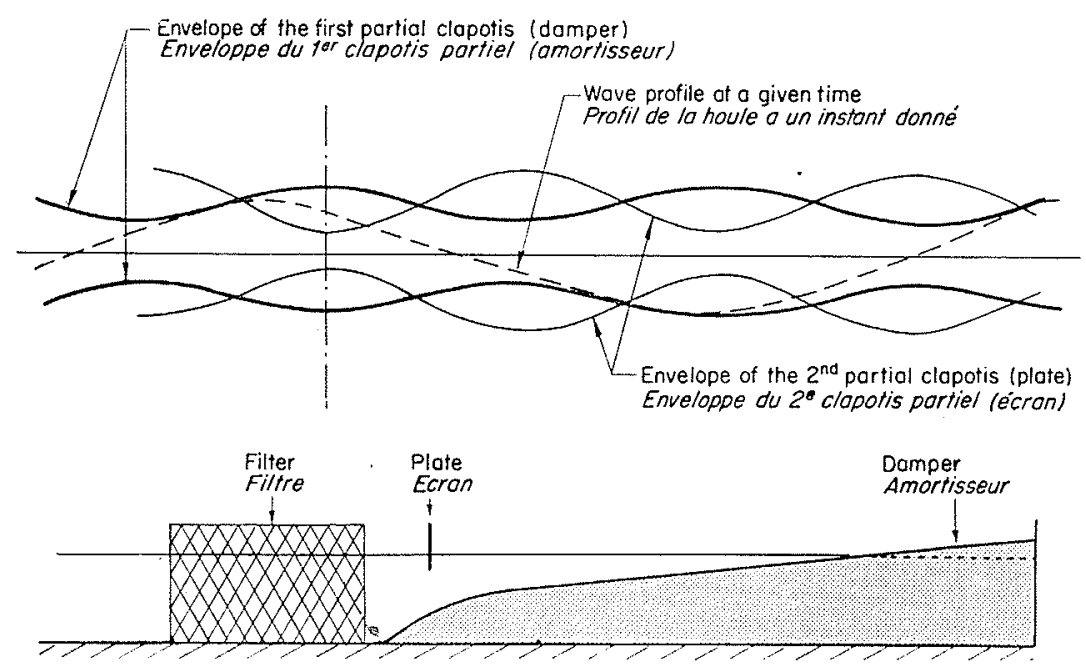

FIi, 4.

vant l'amortisseur imparfait, et à un endroit quelconque, une paroi verticale perpendiculaire à la direction de propagation, jusqu'à ce que le nouveau clapotis partiel engendré soit légèrement prédominant. On peut alors mettre en évidence les ventres et nouds relatifs à cette paroi. On déplace ensuite celle-ci juśqu’à ce que les nouveaux nouds correspondent aux anciens ventres, et inversement.

Il ne reste plus, la position en plan de la paroi 
étant trouvée, qu'à régler son pouvoir réfléchissant, e'est-à-dire à déterminer l'enfoncement convenable. Ceci est obtenu expérimentalement en relevant progressivement la paroi, et en observant l'enveloppe du profil de houle. Pour une certaine position de la paroi, cette enveloppe est très sensiblement une droite.

En pratique, l'interposition d'une paroi réfléchissante devant l'amortisseur à améliorer ne donne pas toujours immédiatement le résultat cherché, du fait que le procédé est valable pour l'amorlissement de l'onde principale, mais non des harmoniques. On est alors amené à placer. un certain nombre de filtres légers, du genre de ceux précédemment décrits, devant l'anortisseur imparfait. On dispose alors la paroi derrière les filtres. Dans tous les cas, l'emploi de ces filtres est de beaucoup préférable à celui du réflecteur seul.
Ce procédé donne des résultats tels que les nouds et les ventres du clapotis partiel de l'ensemble ne sont plus discernables, et qu'il n'est plus possible de déterminer le coafficient de rélexion de l'amortisseur ainsi amélioré.

ETroes rafectues ou na cours. - Cette installation a permis d'entreprendre un certain nombre d'études physiques (la plupart pour le compte de la Direction du Port de Marseille et de la Direction Générale des Concessions de la Chambre de commerce de Marseille), parmi lesquelles nous pouvons citer :

\section{L'étude des profils de houle et de clapotis total} et partiel.

Le cliché de la figure 5 donne une idée de la régularité de la houle obtenue grâce à tous les perfectionnements décrits.

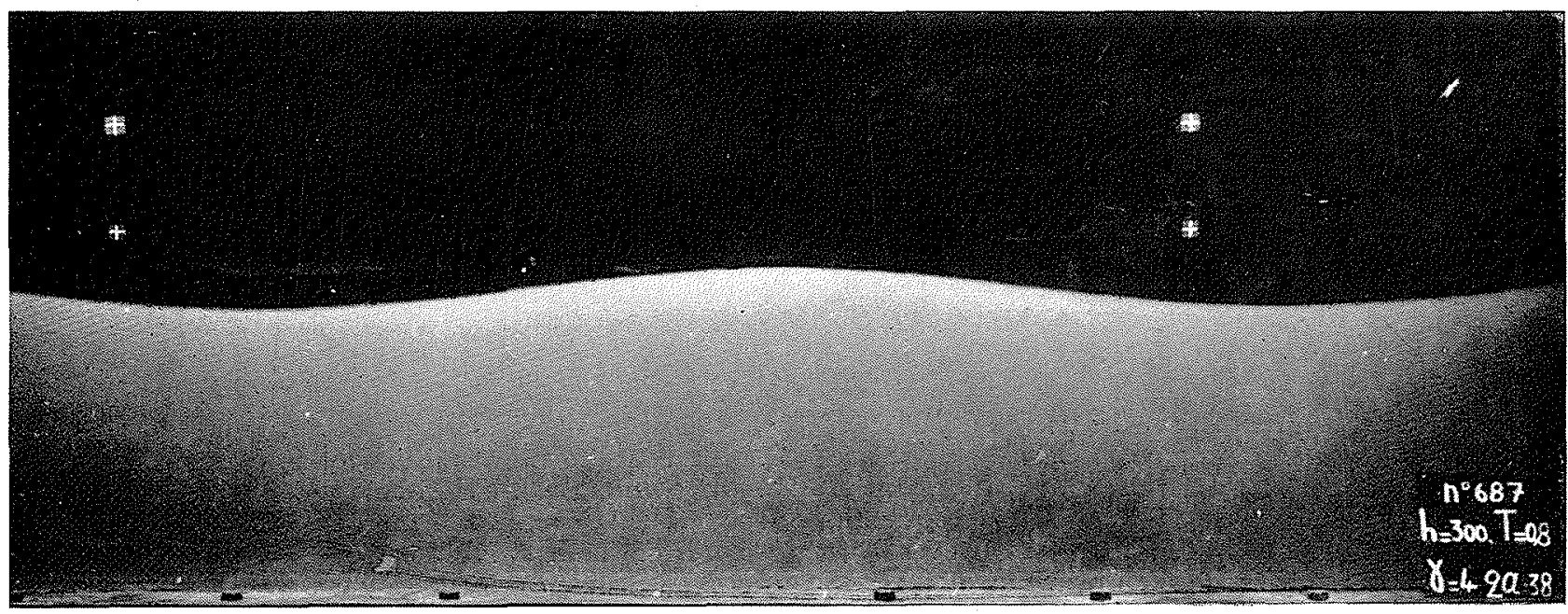

Fiti. 5).

L'étude des trajectoires internes de la houle et du clapotis, poux lesquelles on a pu comparer les données expérimentales avec celles de la théorie, tant au point de vue formes qu'au point de vue dimensions des trajectoires.

L'étude des trajectoires internes dans un clapotis partiel, qui a donné lieu à une suite de photographies, précédemment publiées dans la Howille Blanche. (Trajectoires internes dans un clapotis partiel, par A. Waldet et F. RuelaAN, $\mathrm{n}^{\circ} 4,1950$. )

L'étude des courants internes de la houle.

L'étude de la célérité de la houle qui a permis do confirmer, à $1 \%$ près, la formule donnant la célérité théorique au troisième ordre, formule calculée à partir des travaux de STokes (sur ce dernier point, voir : F. Bresel : Remarques sur la célérité de la houle irrotationnelle exacte au troisieme ordre; la Honille Blanche, n" 3 $1951)$.

l'étude de la houle limite, qui n'est encore qu'amorcée, et qui soulève de grandes difficultés expérimentales. Celles-ci rendront probablement nécessaires d'autres perfectionnements de l'appareillage.

L'étude du clapotis limite, phénomène fugace lui aussi, mais dont a pu mettre en évidence, avec une précision relativement honne, les circonstances de formation.

LABORATORE DAEPHNOIS D'HYDRAULQUE NFyiptC - GRExOBLE. 


\title{
LABORATORY PRACTICE
}

\section{Description of an installation for experimental studies on the physics of waves}

\author{
Texte français, p. 843. \\ See French text, p. 844 for illustrations
}

Investigations which call for the use of experimental waves in a flume nearly always deal with scale models of structure projects, of which the qualities are to be defined; these qualities are, in the main, stability, absorbancy and the ability to prevent the waves from passing over the top of the structure.

This being the case, the generating of waves whose characteristics are constant in time makes it possible to obtain results which are usually sufficiently consistent to enable the comparison of differing types of structures, on the condition that too great a reflection of the waves of the generating machine be avoided.

However, these conditions are far from being sufficient where the physics of waves is concerned, that is to say, when one wishes to deal, with the required accuracy, with the actual structure and the characteristics of the wave phenomenon in order to be able, in particular, to compare these results with theoretical data.

An experimental tool which is especiallyadapted to these physical investigations is therefore necessary. After a long series of modifications and improvements, of which the most characteristic are described in the following, it became possible to obtain waves of an exceptional purity and constance on one of the installations of the Neyrpic Hydraulic Research Laboratory (fig. 1).

This installation was to offer the maximum of experimental possibilities, especially concerning the
Description of arrangements for the generating, purification, and amplification of waves of the maximum purity. Possibility of changing of wave characleristics during operation and b! remote control. Original process for the improvement of damping conditions. generating of very steep waves. It is generally considered that this is incompatible with the use of wave filters; these latter are employed to absorb) wave reflection of the generator but they also absorb some of the energy of incident waves.

The problem was solved by the use of a convergent, placed between the wave generator and the flume, which " concentrates" the energy of the waves and magnifys their amplitude (fig. 2 ).

The design of this convergent is such that it compensates with accuracy the loss of energy resulting from the filter as well as the actual damping itself.

The installation thus comprises : the seaward section, with the wave generator and filters, the convergent, the flume itself, which is partially glasswalled, and the final damper. This layout is completed by a return pipe whose purpose will be described.

Seaward Secriox. - This is formed of three metal elements $0.75 \mathrm{~m}$ in width and $7 \mathrm{~m}$ in total length. Behind the wave generating machine, which is installed in this section, is a rip-rap rock bank designed to absorb the secondary waves generated by the backward movement of the wave machine blade. Two wave filters are placed in front of the wave machine.

Convergent. - The degrec of convergency of this section is very low $(0.45 \mathrm{~m}$ for $11 \mathrm{~m}$ in length) 
so that the perturbation of the wave generating conditions may be reduced to the minimum. A sudden change in cross-section could give rise, for example, to very marked overall transversal surface oscillations, to reflection, etc...

The central section of the two walls is rectilinear and is connected up with the remainder of the installation by a section of a parabola at one end and by a section of a cubic curve (with a zero curve at the connecting point) at the other. This makes it possible to combine the gradual convergency with a very progressive connecting curve.

The walls are made of concrete since metal walls would not have been compatible with the curves used.

The convergent is completed by a set of longitudinal plates to prevent the slight transversal oscillalions which may occur for certain wave periods.

Flume. - This is formed of seven, $2 \mathrm{~m}$ long $(61 / 2 \mathrm{ft})$, metal elements. These elements are made of ridged stainless steel plate similar to that used for the seaward section.

With the exception of the third, all the elements have a perspex observation window in the middle of their side walls.

The third element from the convergent is glasswalled over its entire length for observation and photographic purposes.

RETurn PIPE, - When flume studies are made of a section of more or less impermeable breakwoter over which the waves pass, it is seen that the water level behind the breakwater gradually rises. this creating conditions which are artificial. Under natural conditions, the water passing over the breakwater returns to the sea through a pass, for examole. The water which passes over the model breakwater must, therefore, be able to return to the wave generator. For this purpose, a large diameter pipe (which therefore has a small head loss) connects the sixth flume element with the zone immediately in front of the wave generator.

Wave generating Machine. - This is of the oscillating plane shutter type.

In the system used, which is of the "swing" type, the blade is integral with the central element of a three-bar mechanism. This blade thus has a very complex movement which can be made to resemble that which the molecules of water should have. (See :

"Laboratory wave generating apparatus" by F. BrESEL and F. SuQuet, la Honille Blanche, $\mathrm{n}^{\circ:} 2,1951$, 4, 1951 and 5,1951$)$.

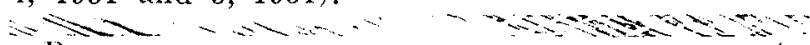

REMOTE CONTROL OF WAVE chaRACTERISTICS. - An original feature of this wave machine is that the parameters on which the wave characteristics depend can be adjusted by remote control and du ring operation.

The movement is transmitted by two rods, between which is placed a lever; the position of one of the pivoting points can be adjusted on this lever by means of an auxiliary motor. The amplitude of the blade movement can thus be regulated by remote control (fig. 3).

In addition, the period of oscillation of the blade is regulated by a speed variation device which, in turn, is also controlled by an auxiliary motor.

It thus becomes possible, from the glass-walled observation section of the flume, to alter the incident wave characteristics (period and amplitude) during operation. This offers a considerable field of possibilities : in particular, one is then able to submit a structure to the action of a series of waves, of which the period or the amplitude, or both together, would be caused to vary according to determined cycles. It is also possible to adjust the wave characteristics with great accuracy in order to produce a determined result, such as the limit steepness of a wave or the presence of "gifles" (" slap", full break against a wall).

Wave finters. - The waves generated by the wave machine pass through a series of filters of the perforated plate type, the principles of which have already been described by Mr. Bresen (la Houille Blanche, May-June 1948).

Here again, it was possible to appreciate the extremely favourable effect of filters for regularizing wave profiles, in addition to their main purpose of absorbing reflected waves.

The design of another type of filter has been perfected : its structure is cell-like and of low density, and it has a very lomogenous, wave energy damping action. Its hydraulic qualities are thus made quite remarkable.

A filter of this type, which could be named a "finishing filter", can be placed between the con. vergent and the glass flume section in order to provide additional improvement of the wave protiles.

Waves bampers. - A damper is provided at the far end of the flume to absorb the energy of the incident waves. This damper can, for example, consist of a very long permeable slope in front of which are placed several filters.

The advantage of this permeable bank is that the loss of energy is again not localized in one particular area of the absorber but is distributed throughout its mass. The profile of the bank is curved, thus forming a very gradual slope near the water surface without entailing an excessive total size.

The efficiency of this profile, which was designed for a given water level, is thus greater than that of a uniform slope.

The effect of this bank, together with that of the filters, thus eliminates reflection at the end of the flume almost entirely, this being sufficient for a great number of investigations such as celerity measurements, transport current measurements, etc... However, the slight residual reflection is troublesome for certain very detailed studies on the actual structure of waves, i.e., research work concerning profile shapes or internal trajectories.

For example, in a case where all the usual precautions are taken to avoid reflection at the end of the flume, it is noted that the slight reflected waves which remain cause the formation of trajectories resembling strings of beads.'

Another method of observation was therefopc necessary, and was perfected according to Mr. BreSEL's theory ("Theoretical study of wave reflection 
on certain obstacles" ... Paper presented to the société Hydrolechnique de France, on June $19 \mathrm{th} 195 \mathrm{I}$ - Summary published in la Houlle Blanche, $n^{\prime \prime} A$, 1952 , page 121).

In the event of slight reflection, the envelope of the wave profile during propagation is formed of two curves, of which the maximum and minimum correspond to what are termed the nodes and antinodes of the partial clapotis. If a second reflection can be created, so that the nodes and antinodes of this second partial clapotis coincide with the antinodes and nodes of the first, the two reflections should cancel each other ont and the incident wave will be pure.

This can, indeed, be achieved experimentally. The second reflection is created in the following way : the two envelopes of the incident waves are observed and the nodes and antinodes of the partial clapotis are situated as accurately as possible. A vertical plate is then partly lowered anywhere in fronl of the imperfect damper and perpendicular to the direction of propagation, and is maintained in position until the new partial clapotis thus created predominates slightly. The nodes and antinodes created by the plate become visible. The position of the plate is then adjusted so that the new nodes occur in the same place as the old antinodes and vice versa (fig. 4).

The correct plane position of the plate having now been found, it remains simply to adjust its "reflectability", i.e, the degree to which it is lowered in the water. This is done experimentally by progressively raising the plate and observing the effect of this on the wave profile envelope. For a certain position of the plate, this surface is approximately a straight line.

In practice, the interposal of a reflecting plate in rront of the damper to be improved does not always give the result sought after immediately, since the process is valid for damping the main wave but not the harmonics. This being the case, it becomes necessary to place a certain number of light-weight filters (as described above) in lront of the faulty damper, and the plate is then placed behind the filters. In all cases, the use of these filters is lighly preferable to the use of the reflector alone.
The results of this arrangement are such that the nodes and antinodes of the partial clapotis of the whole system are no longer discernable and that the reflection coefficient of the improved damper is beyond determination.

PAST AND pRESENT RESEARCH. - This installation has made it possible to undertake a certain number of physical investigations (specially for the Marseilles Harbour Authority and for the "Direction générale des Concessions" of the Marseilles Chamber of Commerce), amongst which mention may be made of the following:

study of wave profiles, study of total and partial clapolis profiles. - The illustration (fig. 5) shows the regularity of the waves which was obtained by means of the installation described

stualy of internal trajectories of waves and clapotis, for which it was possible to compare experimental and theoretical data concerning both their size and shape.

Sludy of internal trajectories of waves and partial clapotis, of which a series of photographs was taken and published in a former issue of la Houlle Blanche (Internal trajectories in a partial clapotis, by A. Wallet and F. Ruellax, no ${ }^{\circ} 4,1950$ ).

Stady of internal currents in loaves. Study of wave celerily, which made possible to confirm, to within $1 \%$, the formula giving the theoretical celerity to the 3rd order; the calculation of this formula was based on Stokes' work (see article by F. Bresse "Remarks on the celerity of irrotational waves to the 3rd order", la Honille Blanche, n" 3 , 1951).

Study of limit waves, which has only just been startad and which gives rise to very great experimental difficulties. These will probably necessitate the further improvement of the installation.

Study of limit clapotis - another transient phenomenon but one for which it las been possible to show, with relative accuracy, the circumstances in which it is formed.

Labonatorre Dacphinots n'Hyoradugete Neytric: - Grenobre. 